\title{
Dry season occurrence of Anopheles mosquitoes and implications in Jabi Tehnan District, West Gojjam Zone, Ethiopia
}

\author{
Abebe Animut ${ }^{*}$ and Yohannes Negash
}

\begin{abstract}
Background: Generating evidence on the dry season occurrence of the larval and adult stages of Anopheles mosquitoes helps to design effective malaria vector control strategy as the populations of the vectors is expected to be low.

Methods: Larval and adult stages of Anopheles were surveyed during dry seasons in Mender Meter, Jiga Yehlmidar and Wongie Berkegn villages, Jabi Tehnan District, West Gojjam Zone, Ethiopia. Larvae were surveyed (along the available surface water collections), sampled, identified into genus, counted and late instars of the genus Anopheles identified into species. Indoor-resting adult mosquitoes were collected using insecticide aerosol spray, processed and identified into species. Data was analysed using SPSS version 20.0 to determine frequencies, mean differences and associations.

Results: A total of 3127 Anopheles larvae were collected among which most (91.7\%; 2869/3127) were from streams followed by ponds $(4.3 \% ; 136 / 3127)$ and swamps $(3.9 \% ; 122 / 3127)$. Anopheles gambiae sensu lato was the most prevalent (84.9\%; 921/1085) followed by Anopheles cinereus (7.0\%; 76/1085), Anopheles chrysti (3.7\%; 40/1085), Anopheles demeilloni (2.8\%; 30/1085) and Anopheles rhodesiensis (1.6\%; 18/1085). The mean number (mean=15.3) of An. gambiae from Jiga Yehlmidar was significantly $(p=0.024)$ higher than the corresponding number $(m e a n=3.2)$ from Mender Meter. The mean number (mean $=36.3)$ of An. gambiae larvae in April 2017 was significantly $(p=0.001)$ higher than the number (mean=4.0) in December 2013 and the number (mean=2.6) in March 2013. A total of 1324 adult Anopheles were collected of which the highest proportion (79.1\%; 1048/1324) was An. gambiae, followed by An. chrysti (11.7\%; 155/1324), An. demeilloni (6\%; 80/1324), An. cinereus (2.6\%; 35/1324) and Anopheles coustani (0.5\%; 6/1324). The highest proportion (54.3\%; 569/1048) of the An. gambiae was collected from Wongie Berkegn followed by Jiga Yehlmidar $(23.6 \% ; 247 / 1048)$ and Mender Meter $(22.1 \% ; 232 / 1048)$. The mean number (mean =7.8) of adult An. gambiae caught in Wongie Berkegn was significantly $(p=0.018)$ higher compared to the number $(m e a n=3.0)$ in Mender Meter. No significant difference was observed in the mean number of adult An. gambiae between the seasons.
\end{abstract}

Conclusion and implication: Streams were prolific breeding habitats of Anopheles mosquitoes followed by ponds and swamps in the dry seasons. In addition, a high population of indoor resting An. gambiae was caught from indoors. This implies the need for a strengthened vector control during dry seasons using breeding habitat management and improved housing in addition to the existing insecticide (LLINs and IRS) based interventions in Jabi Tehnan District, West Gojjam Zone, Ethiopia. 


\section{Background}

Malaria vectors undergo egg, larval, pupal and adult stages in their life time. Their egg, larval and pupal stages are limited to water bodies and have very small spatial dispersion. In dry seasons, the number and size of larval habitats is generally believed to reduce significantly and contribute to a low population of malaria-transmitting adult Anopheles [1-3]. The narrow spatial dispersion and low population size of the immature vectors make them more amenable to environmental management $[4,5]$. Thus, larval habitat management can best be implemented in dry seasons in the fight against malaria vectors. Even so, Anopheles species exploit a variety of breeding habitats that vary considerably in size, altitude, vegetation cover and topography $[1$, $6,7]$. In a narrow topographic area, breeding habitats can have enormous variability in their anopheline productivity [7-9]. The majority of vectors may emerge from prolific habitats, which could account only for a small proportion of the habitats. Thus, effective larval interventions can be achieved through targeting productive habitats during dry seasons [6].

After emergence from pupal stage, malaria-transmitting adult female Anopheles undertake mating with their male counterparts and find human blood meal to nourish their eggs. They imbibe blood mainly during night hours inside residential houses and rest in door until their blood meal is digested and eggs are matured. Accordingly, insecticide-impregnated mosquito nets and residual insecticide sprays are employed inside houses to prevent and kill indoor biting and indoor resting vectors, respectively. In dry seasons, the adult vector population may reduce significantly owing to the reduction in breeding habitats $[2,3,10]$. Even so, some may survive due to factors, such as behavioural adaptation and insecticide resistance $[4,11]$. They may prefer some housing conditions over others [12] and show a pattern of clustering in which case a great majority of them could occur inside smaller proportion of the houses built near their breeding habitats.

The relatively small populations of aquatic and adult stages in dry seasons could explode to very large populations during and immediately after wet seasons. Wet seasons usually make vector control interventions more difficult and expensive compared to the dry seasons in areas where dryness is associated with rare and highly limited breeding habitats. In such areas, control on larval and adult vector populations during the dry seasons can cause a significant reduction on the existing vector populations and could delay or reduce vector population explosion during and following the rains. Dry season occurrence of malaria vectors was assessed through surveys of immature and adult Anopheles in Jabi Tehnan District, West Gojjam Zone, Ethiopia.

\section{Methods}

\section{Study area}

The study was undertaken in Mender Meter [1912 m above sea level (m.a.s.l.)], Jiga Yehlmidar (1818 m.a.s.l.), and Wongie Berkegn (1786 m.a.s.l.) villages of Jabi Tehnan District, West Gojjam Zone, Ethiopia where malaria is endemic $[13,14]$. These villages were also used to study the distribution and use of vector control tools [13] and current malaria prevalence [14]. In each village, available surface water collections (streams, swamps, ponds, irrigation channels) and water wells were surveyed for Anopheles larvae. The streams cross pasture and farm lands while the swamps and ponds were located in the pasture lands. In each village, a minimum of 10 randomly selected houses, located within a radius of $1 \mathrm{~km}$ from the nearest stream/breeding habitat were surveyed during each season.

\section{Survey of malaria vector breeding habitats}

Larval and adult stages Anopheles were surveyed during three dry seasons (March 15-20, 2013, December 19-21, 2013 and April 17-20, 2017). Potential mosquito breeding habitats were first inspected for the presence of mosquito larvae visually and positive habitats were sampled with a $350 \mathrm{ml}$ capacity soup ladle. The water was left to settle until larvae came to the surface after each subsequent dipping. Ten dips were made from each potential breeding habitat, each dip having a volume of about $80 \%$ of the liquid holding capacity of the ladle to prevent spill off. The larvae from the dipper were transferred to white enamel trays for further categorization into genus and instars. Anopheles larvae were categorized as first instar, second instar, third instar and/or fourth instar. Early Anopheles larval instars (first and second) were discarded after counting. The late Anopheles larval instars were preserved in $70 \%$ alcohol after they were killed in hot water (ca. $60^{\circ} \mathrm{C}$ ), mounted in gum-chloral mountant on microscopic slides and morphologically identified to species under microscope $[15,16]$. Larval sampling was made by the first author (AA) from 11:00 am to 2:00 pm.

\section{House survey for indoor-resting Anopheles}

A survey of indoor-resting Anopheles was made during three dry seasons (March 16-18, 2013, December 20, 2013-January 2, 2014 and April 16-18, 2017) using insecticide aerosol spray. The insecticide aerosol, named Roach Killer, contained Fenithrothion, Cypermethrin and Bioallethrin active ingredients. The spray was made in the morning (7:00 am to 8:30 am). Before spraying occupants, domestic animals, utensils used for food, food, drinking water and clothes were taken out of houses. The major house apertures were covered with clothes, and the available floor space was covered by white plastic 
sheets. Spraying was made according to the manufacturer's instruction and collectors waited outside for about $10 \mathrm{~min}$. The sheet was then carefully taken out of the house and knocked down mosquitoes were collected using forceps $[17,18]$.

Female anophelines of all catches were counted and identified morphologically to species under dissecting microscope $[16,19]$. Condition of each spray house including altitude, presence of open eave, door fitness, presence of hole on wall/roof, presence of window, type of roof (thatched/corrugated iron), number of people slept inside the house the previous night, number of domestic animals (cattle, sheep, goat, horse, donkey, chicken) tethered inside the house the previous night, presence of bed net, number of people who slept under bed net the previous night, and house distance from the nearest breeding site were recorded [12].

\section{Statistical analysis}

Data were entered and analysed using IBM SPSS Statistics Version 20.0. Frequencies of aquatic stages and indoor resting Anopheles were determined. One-Way ANOVA analysis with Tukey Post-Hoc tests was used to compare the differences in the mean number of larval and indoor-resting adult stages of Anopheles gambiae sensu lato (An. gambiae thereafter) between seasons and villages after $\log (\mathrm{x}+1)$ transformed. Association of the variables of the major housing conditions with the transformed An. gambiae was analysed using binary and multiple regression in order to determine the strong predictor variable(s). Variables with $\mathrm{p}$ values $<0.05$ were considered significant.

\section{Results}

\section{Anopheles larvae occurrence and distribution}

A total of 3127 Anopheles larvae were collected from the available surface water collections from Mender Meter, Jiga Yehlmidar and Wongie Berkegn villages in March 2013, December 2013 and April 2017 (Table 1). The highest number $(\mathrm{n}=2077)$ of Anopheles larvae catches was made in Wongie Berkegn followed by Jiga Yehlmidar $(n=655)$, and Mender Meter $(n=395)$. Density of larvae was highest in April, $2017(\mathrm{n}=2011)$ followed by March $2013(n=612)$ and December $2013(n=504)$. The streams contributed to the great majority of the larvae caught $(91.7 \%$; $2869 / 3127)$ followed by the ponds $(4.3 \%$; $136 / 3127)$ and swamps (3.9\%; 122/3127). From among the total Anopheles larvae, 62.6\% (1958/3127) were early instars and $37.4 \%(1169 / 3127)$ were late instars.

Among a total of 1169 late instar Anopheles larvae, 92.8\% (1085/1219) were morphologically identified into species (Table 2). Anopheles gambiae was the most prevalent (84.9\%; 921/1085) followed by Anopheles cinereus (7.0\%; 76/1085), Anopheles chrysti (3.7\%; 40/1085), Anopheles demeilloni (2.8\%; 30/1085) and Anopheles rhodesiensis (1.6\%; 18/1085). Density of An. gambiae was highest in Wongie Berkegn $(72.1 \%$; 664/921) followed by Jiga Yehlmidar $(23.6 \%$; 217/921) and Mender Meter $(4.3 \% ; 40 / 921)$. The mean number $($ mean $=15.5)$ of An. gambiae from Wongie Berkgen was significantly $(\mathrm{p}=0.011)$ higher than the corresponding number $($ mean $=3.2)$ from Mender Meter. The mean number (mean =15.3) of An. gambiae from Jiga Yehlmidar was significantly $(\mathrm{p}=0.024)$ higher than the corresponding number $($ mean $=3.2)$ from Mender Meter. No significant

Table 1 Occurrence of Anopheles larvae by village, season and habitat type in Jabi Tehnan District, West Gojjam Zone, Ethiopia, March 2013-April 2017

\begin{tabular}{|c|c|c|c|c|c|c|c|c|c|}
\hline Village & Season & Habitat & 1st instar & 2nd instar & 3 rd instar & 4th instar & Total & Season total & Village total \\
\hline \multirow[t]{5}{*}{ Mender Meter } & Mar 2013 & Stream & 0 & 0 & 0 & 0 & 0 & 0 & 395 \\
\hline & & Pond & 0 & 0 & 0 & 0 & 0 & & \\
\hline & Dec 2013 & Stream & 45 & 70 & 54 & 34 & 203 & 311 & \\
\hline & & Pond & 39 & 25 & 23 & 21 & 108 & & \\
\hline & Apr 2017 & Stream & 33 & 19 & 21 & 11 & 84 & 84 & \\
\hline \multirow[t]{6}{*}{ Jiga Yehlmidar } & Mar 2013 & Stream & 35 & 24 & 26 & 13 & 98 & 98 & 655 \\
\hline & Dec 2013 & Stream & 9 & 7 & 12 & 2 & 30 & 94 & \\
\hline & & Pond & 1 & 8 & 16 & 3 & 28 & & \\
\hline & & Swamp & 6 & 1 & 13 & 16 & 36 & & \\
\hline & Apr 2017 & Stream & 156 & 66 & 94 & 61 & 377 & 463 & \\
\hline & & Swamp & 26 & 11 & 27 & 22 & 86 & & \\
\hline \multirow[t]{3}{*}{ Wongie Berkegn } & Mar 2013 & Stream & 227 & 201 & 58 & 28 & 514 & 514 & 2077 \\
\hline & Dec 2013 & Stream & 80 & 12 & 6 & 1 & 99 & 99 & \\
\hline & Apr 2017 & Stream & 470 & 387 & 357 & 250 & 1464 & 1464 & \\
\hline Total & & & 1127 & 831 & 707 & 462 & 3127 & 3127 & 3127 \\
\hline
\end{tabular}


Table 2 Species distribution of Anopheles larvae by village and habitat type in Jabi Tehinan District, West Gojjam Zone, Ethiopia, March 2013-April 2017

\begin{tabular}{|c|c|c|c|c|c|c|c|c|}
\hline \multirow[t]{2}{*}{ Season } & \multirow[t]{2}{*}{ Species } & \multicolumn{2}{|c|}{ Mender Meter } & \multicolumn{3}{|c|}{ Jiga Yehlmidar } & \multirow{2}{*}{$\begin{array}{l}\text { Wongie Berkegn } \\
\text { Stream }\end{array}$} & \multirow[t]{2}{*}{ Total } \\
\hline & & Stream & Pond & Stream & Pond & Swamp & & \\
\hline \multirow[t]{5}{*}{ Mar 2013} & An. gambiae & 0 & 0 & 5 & 0 & 0 & 72 & 77 \\
\hline & An. cinereus & 0 & 0 & 0 & 0 & 0 & 6 & 6 \\
\hline & An. chrysti & 0 & 0 & 0 & 0 & 0 & 1 & 1 \\
\hline & An. demeilloni & 2 & 0 & 0 & 0 & 0 & 2 & 4 \\
\hline & An. rhodesiensis & 0 & 0 & 0 & 0 & 0 & 1 & 1 \\
\hline \multirow[t]{5}{*}{ Dec 2013} & An. gambiae & 12 & 1 & 13 & 12 & 28 & 7 & 73 \\
\hline & An. cinereus & 36 & 3 & 0 & 3 & 0 & 0 & 42 \\
\hline & An. demeilloni & 0 & 2 & 0 & 0 & 0 & 0 & 2 \\
\hline & An. chrysti & 0 & 0 & 0 & 6 & 0 & 0 & 6 \\
\hline & An. rhodesiensis & 15 & 0 & 0 & 1 & 0 & 0 & 16 \\
\hline \multirow[t]{5}{*}{ Apr 2017} & An.gambiae & 27 & 0 & 124 & 0 & 35 & 585 & 771 \\
\hline & An. cinereus & 2 & 0 & 13 & 0 & 6 & 7 & 28 \\
\hline & An. chrysti & 1 & 0 & 12 & 0 & 3 & 17 & 33 \\
\hline & An. demeilloni & 9 & 0 & 5 & 0 & 5 & 5 & 24 \\
\hline & An. rhodesiensis & 0 & 0 & 0 & 0 & 0 & 1 & 1 \\
\hline Total & & 104 & 6 & 172 & 22 & 77 & 704 & 1085 \\
\hline
\end{tabular}

difference was observed in the mean numbers of $A n$. gambiae collections between Jiga Yehlmidar and Wongie Berkegn. The mean number (mean $=36.3)$ of An. gambiae larvae in April 2017 was significantly $(\mathrm{p}=0.001)$ higher than the number $($ mean $=4.0)$ in December 2013 and the number $($ mean $=2.6)$ in March 2013. Similarly, the mean number of catches in March 2013 was significantly $(\mathrm{p}<0.05)$ different from the number in December 2013. An. gambiae, the most prevalent mosquito in the area, was found to breed along streams, swamps and ponds. Water wells and irrigation channels were positive for culicine larvae but negative for Anopheles larvae. Streams were the most productive habitats of An. gambiae $(91.7 \%$; 845/921) followed by swamps $(6.8 \% ; 63 / 921)$ and ponds $(1.5 \% ; 14 / 921)$.

\section{In-door occurrence of adult Anopheles mosquitoes and their determinants}

A total of 1324 adult Anopheles mosquitoes were collected from indoors by aerosol spray sheet collection (ASC) (Table 3). Among these, the highest proportion (79.1\%; 1048/1324) was An. gambiae, followed by An. chrysti (11.7\%; 155/1324), An. demeilloni (6\%; 80/1324), An. cinereus (2.6\%; 35/1324) and Anopheles coustani $(0.5 \% ; 6 / 1324)$. The highest proportion $(54.3 \% ; 569 / 1048)$ of the An. gambiae was collected from Wongie Berkegn followed by Jiga Yehlmidar $(23.6 \% ; 247 / 1048)$ and Mender Meter (22.1\%; 232/1048). The mean number (mean $=7.8$ ) of adult An. gambiae caught in Wongie
Berkegn was significantly $(\mathrm{p}=0.018)$ higher compared to the number $($ mean $=3.0)$ in Mender Meter. The difference in the mean number of indoor-resting An. gambiae between Jiga Yehlmidar and Wongie Berkegn was not statistically significant. Density of An. chrysti was also observed to have a similar trend with that of An. gambiae, but An. demeilloni was found to decrease with a decrease in altitude.

Adult An. gambiae $(\mathrm{n}=394)$ caught in April 2017 was the highest followed by December 2013-January 2014 $(\mathrm{n}=350)$ and March $2013(\mathrm{n}=304)$. However, no significant difference was observed in the mean number of the adult An. gambiae between the seasons. The indoor occurrence of An. gambiae was similar among all the housing conditions as analysed by the regression statistics. None of the variables of the housing conditions was strongly associated with the density of indoor resting $A n$. gambiae and also none was found to be a strong predictor of indoor resting An. gambiae in the villages.

\section{Discussion}

Streams were the most prolific breeding habitats of Anopheles followed by ponds and swamps. The great majority of larvae inhabiting these habitats were $A n$. gambiae, followed by An. cinereus and An. chrysti. In Ethiopia, Anopheles arabiensis, a sibling species in the An. gambiae complex, is widely distributed and remains a major malaria vector throughout the country. Previous 
Table 3 Occurrence of adult Anopheles species by season and village in Jabi Tehinan District, West Gojjam Zone, Ethiopia, March 2013-April 2017

\begin{tabular}{|c|c|c|c|c|c|}
\hline Season & Species & $\begin{array}{l}\text { Mender Meter } \\
\mathrm{N}\end{array}$ & $\begin{array}{l}\text { Jiga Yehlmidar } \\
\mathrm{N}\end{array}$ & $\begin{array}{l}\text { Wongie Berkegn } \\
\mathrm{N}\end{array}$ & Tota \\
\hline \multirow[t]{5}{*}{ Mar 2013} & An. gambiae & 6 & 107 & 191 & 304 \\
\hline & An. chrysti & 7 & 28 & 3 & 38 \\
\hline & An. demeilloni & 1 & 7 & 1 & 9 \\
\hline & An. cinereus & 0 & 10 & 0 & 10 \\
\hline & An. coustani & 0 & 2 & 0 & 2 \\
\hline \multirow[t]{5}{*}{ Dec 2013-Jan 2014} & An. gambiae & 109 & 64 & 177 & 350 \\
\hline & An. chrysti & 2 & 8 & 36 & 46 \\
\hline & An. demeilloni & 33 & 8 & 6 & 47 \\
\hline & An. cinereus & 2 & 5 & 0 & 7 \\
\hline & An. coustani & 0 & 0 & 1 & 1 \\
\hline \multirow[t]{5}{*}{ Apr 2017} & An. gambiae & 117 & 76 & 201 & 394 \\
\hline & An. chrysti & 0 & 15 & 56 & 71 \\
\hline & An. demeilloni & 0 & 15 & 9 & 24 \\
\hline & An. cinereus & 0 & 18 & 0 & 18 \\
\hline & An. coustani & 0 & 0 & 3 & 3 \\
\hline Total & & 277 & 363 & 684 & 1324 \\
\hline
\end{tabular}

studies reported occurrence of An. arabiensis and other species of Anopheles larvae along streams in a central highland area [18] and in the middle course of the rift valley [20] of Ethiopia. Studies from other east African countries also support this observation [21-23].

Abundance of An. gambiae larvae along streams and also in ponds and swamps during dry seasons entails a strengthened vector control strategy in the habitats against aquatic stages of anophelines during the seasons. Management of the streams during dry seasons can reduce the vector populations significantly as the aquatic stages (eggs, larvae and pupae) of mosquitoes remain confined within relatively small habitats and cannot readily escape control measures [6, 24-26]. Disruption of the aquatic stages of mosquitoes during the dry seasons would decrease the size of an already small population, and may delay an explosive build-up of the vector populations towards the end of dry seasons, during the onset of the rainy seasons and following the rains in inland villages $[10,19,24,27]$. It can also serve as an alternative control strategy to malaria transmitting vectors that are resistant to the available insecticide based control tools (such as LLINs and IRS) [28-30] and hence can be highly effective in controlling malaria transmission in Jabi Tehnan district if used and also integrated in the current malaria vector control package [4]. As the streams are used for washing clothes and as sources of drinking water for cattle (personal observation during the study), chemical based larval intervention cannot be employed. Instead, temporary and scheduled manipulation of the habitats such as straightening, flashing and changing their course can be employed.

Indoor spray catches revealed occurrence of adults of An. gambiae, An. chrysti, An. demeilloni, An. cinereus and An. coustani in a decreasing order of density. Anopheles gambiae, which comprises An. arabiensis and Anopheles amharicus in Ethiopia, was the most frequently caught mosquito. Most previous studies reported An. arabiensis from different parts of the country and is the main vector of malaria, while An. amharicus (formerly Anopheles quadriannulatus species B) was described to occur in the country [30-33]. An. arabiensis is most frequently reported to occur in dry seasons than any other species in the An. gambiae [18, 25, 34]. Hence, the An. gambiae catches can presumably be considered as An. arabiensis and could be considered the primary vector responsible for the transmission of Plasmodium falciparum and Plasmodium vivax malaria in the area during the seasons [13, 14]. However, it remains important to incriminate $A n$. cinereus, An. chrysti, An. demeilloni and An. coustani for their vectorial role in the area.

The houses from where adult mosquitoes surveyed, both located within $1 \mathrm{~km}$ radius from a nearby permanent breeding habitat, were observed to have similar density of indoor resting An. gambiae. This could partly be explained by the similar housing conditions and the indoor occurrence of the blood meal sources readily in every house during the night hours. However, this observation differs from previous studies in which case the indoor density of Anopheles varied significantly among 
houses within the same village $[12,25,35,36]$. The indoor occurrence of the vectors could maintain transmission of the malaria during the dry season and serve as sources for increased transmission intensity in the villages at the time of vector population built up [27]. In the area, the domestic animals and humans share the same house in the night creating favourable blood meal source for the mosquitoes. Species of the An. gambiae complex feed during night hours and An. arabiensis a species in the complex feeds on humans and cattle alternatively [17]. This may suggest the possibility of indoor feeding and resting activity of the An. gambiae in Jabi Tehnan District.

The occurrence of adult anopheline mosquitoes inside residential houses indicates the need for proper utilization of existing malaria vector control tools namely the insecticide treated mosquito nets and indoor residual spraying. The use of improved housing conditions remains a top priority in view of the increasing abundance of insecticide resistant malaria vectors and also sustaining the low level transmission of malaria in the district.

It was not possible to carry out immature and adult Anopheles survey during every month of the year and hence describe the peak and low Anopheles density season(s). As a result it was not possible to clearly describe occurrence of the mosquitoes and the respective prolific breeding habitats during other seasons. It was not also possible to test the sporozoite infection status of the mosquitoes due to the shortage of reagents.

\section{Conclusion}

The streams were prolific breeding habitats of Anopheles followed by ponds and swamps during dry seasons in Jiga Yehlmidar, Mender Meter and Wongie Berkegn villages, Jabi Tehnan District, West Gojjam Zone, Ethiopia. A high population of indoor resting Anopheles gambiae, followed by An. cinereus, An. chrysti, An. demeilloni and $A n$. coustani were caught in the villages during the seasons. This implies the need to carry out management of breeding habitats, improved housing and scaled-up use of insecticide (LLINs and IRS) based adult vector control tools, during dry seasons, to decrease the population of malaria transmitting Anopheles mosquitoes in the villages.

\section{Authors' contributions}

AA conceived and designed the study. AA and $\mathrm{YN}$ collected and analysed the data. AA wrote the manuscript. AA and YN reviewed the manuscript. Both authors read and approved the final manuscript.

\section{Acknowledgements}

The authors would like to thank the West Gojjam Zone and Jabi Tehnan District Health Bureaus for their provision to undertake the study. The authors thank the households of Mender Meter, Jiga Yehlmidar and Wongie Berkegn villages for their collaboration during the indoor spray adult mosquito collection and immature mosquito surveys. We also thank Ato Nega Nigussie for his technical support during the data collection.

\section{Competing interests}

The authors declare that they have no competing interests.

\section{Availability of data and materials}

The data supporting conclusion of this article are included within the article.

\section{Consent for publication}

Not applicable.

\section{Ethics approval and consent to participate}

The study was reviewed and approved by the Institutional Review Board of the Aklilu Lemma Institute of Pathobiology, Addis Ababa University. Permission to undertake the study was obtained from West Gojjam Zone and Jabi Tehnan District Health Bureaus. Informed verbal consent was obtained from all the selected study households after the study was explained to them in the local language (Amharic) [13].

\section{Funding}

The study obtained financial support from the Addis Ababa University, Office of the Vice President for Research and Technology Transfer.

\section{Publisher's Note}

Springer Nature remains neutral with regard to jurisdictional claims in published maps and institutional affiliations.

Received: 19 September 2018 Accepted: 26 November 2018

Published online: 29 November 2018

\section{References}

1. Minakawa N, Mutero CM, Githure JI, Beier JC, Yan G. Spatial distribution and habitat characterization of anopheline mosquito larvae in Western Kenya. Am J Trop Med Hyg. 1999;61:1010-6.

2. Govoetchan R, Gnanguenon V, Ogouwale E, Oke-Agbo F, Azondekon $\mathrm{R}$, Sovi $A$, et al. Dry season refugia for anopheline larvae and mapping of the seasonal distribution in mosquito larval habitats in Kandi, northeastern Benin. Parasit Vectors. 2014;7:137.

3. Himeidan YE, Zhou G, Yakob L, Afrane Y, Munga S, Atieli H, et al. Habitat stability and occurrences of malaria vector larvae in western Kenya highlands. Malar J. 2009:8:234.

4. Killeen GF, Fillinger U, Knols BG. Advantages of larval control for African malaria vectors: Iow mobility and behavioural responsiveness of immature mosquito stages allow high effective coverage. Malar J. 2002;1:8.

5. Killeen GF, Fillinger U, Kiche I, Gouagna LC, Knols BG. Eradication of Anopheles gambiae from Brazil: lessons for malaria control in Africa? Lancet Infect Dis. 2002;2:618-27.

6. Gu W, Novak RJ. Habitat-based modeling of impacts of mosquito larval interventions on entomological inoculation rates, incidence, and prevalence of malaria. Am J Trop Med Hyg. 2005;73:546-52.

7. Minakawa N, Dida GO, Sonye GO, Futami K, Njenga SM. Malaria vectors in Lake Victoria and adjacent habitats in western Kenya. PLOS ONE. 2012;7:e32725

8. Fillinger U, Sombroek H, Majambere S, van Loon E, Takken W, Lindsay SW. Identifying the most productive breeding sites for malaria mosquitoes in the Gambia. Malar J. 2009;8:62.

9. Minakawa N, Omukunda E, Zhou G, Githeko A, Yan G. Malaria vector productivity in relation to the highland environment in Kenya. Am J Trop Med Hyg. 2006;75:448-53.

10. Jawara M, Pinder M, Drakeley CJ, Nwakanma DC, Jallow E, Bogh C, et al. Dry season ecology of Anopheles gambiae complex mosquitoes in The Gambia. Malar J. 2008;7:156. 
11. Bogh C, Pedersen EM, Mukoko DA, Ouma JH. Permethrin-impregnated bednet effects on resting and feeding behaviour of lymphatic filariasis vector mosquitoes in Kenya. Med Vet Entomol. 1998;12:52-9.

12. Animut A, Balkew M, Lindtjorn B. Impact of housing condition on indoorbiting and indoor-resting Anopheles arabiensis density in a highland area, central Ethiopia. Malar J. 2013;12:393.

13. Animut A, Negash $Y$, Kebede N. Distribution and utilization of vector control strategies in a malarious village of Jabi Tehnan District, north-western Ethiopia. Malar J. 2014;13:356.

14. Ayalew S, Mamo H, Animut A, Erko B. Assessment of current malaria status in light of the ongoing control interventions, socio-demographic and environmental variables in Jiga Area, Northwest Ethiopia. PloS ONE. 2016;11:e0146214.

15. WHO. Malaria entomology and vector control: Learner's Guide. Trial Edition HIV/AIDS, Tuberculosis and Malaria, Roll Back Malaria 2003.

16. Gillies MT, Coetzee M. A supplement to the Anophelinae of Africa south of the Sahara (Afrotropical Region). Publ South Afr Inst Med Res. 1987:55:1-143.

17. Animut A, Balkew M, Gebre-Michael T, Lindtjorn B. Blood meal sources and entomological inoculation rates of anophelines along a highland altitudinal transect in south-central Ethiopia. Malar J. 2013;12:76.

18. Animut A, Gebre-Michael T, Balkew M, Lindtjorn B. Abundance and dynamics of anopheline larvae in a highland malarious area of southcentral Ethiopia. Parasit Vectors. 2012;5:117.

19. WHO. Manual on practical entomology in malaria. Part II. Methods and techniques division of malaria and other parasitic diseases Geneva; 1975.

20. Kenea O, Balkew M, Gebre-Michael T. Environmental factors associated with larval habitats of anopheline mosquitoes (Diptera: culicidae) in irrigation and major drainage areas in the middle course of the Rift Valley, central Ethiopia. J Vector Borne Dis. 2011;48:85-92.

21. Minakawa N, Githure Jl, Beier JC, Yan G. Anopheline mosquito survival strategies during the dry period in western Kenya. J Med Entomol. 2001;38:388-92

22. Imbahale SS, Paaijmans KP, Mukabana WR, van Lammeren R, Githeko AK, Takken W. A longitudinal study on Anopheles mosquito larval abundance in distinct geographical and environmental settings in western Kenya. Malar J. 2011;10:81.

23. Shililu J, Mbogo C, Ghebremeskel T, Githure J, Novak R. Mosquito larval habitats in a semiarid ecosystem in Eritrea: impact of larval habitat management on Anopheles arabiensis population. Am J Trop Med Hyg. 2007;76:103-10

24. WHO. Larval Source Managment: A supplementary measure for malaria vector control: an operational manual. Geneva: World Health Organization; 2013.
25. Minakawa N, Seda P, Yan G. Influence of host and larval habitat distribution on the abundance of African malaria vectors in western Kenya. Am J Trop Med Hyg. 2002;67:32-8.

26. Yohannes M, Haile M, Ghebreyesus TA, Witten KH, Getachew A, Byass $P$, et al. Can source reduction of mosquito larval habitat reduce malaria transmission in Tigray, Ethiopia? Trop Med Int Health. 2005;10:1274-85.

27. Baber IKM, Sogoba N, Konate M, Diallo M, Doumbia S, Traore SF, et al. Population size and migration of Anopheles gambiae in the Bancoumana Region of Mali and their significance for efficient vector control. PLoS ONE. 2010;5:e10270.

28. Yewhalaw D, Wassie F, Steurbaut W, Spanoghe P, Van Bortel W, Denis L, et al. Multiple insecticide resistance: an impediment to insecticide-based malaria vector control program. PLOS ONE. 2011;6:e16066.

29. Balkew M, Elhassen I, Ibrahim M, Gebre-Michael T, Engers H. Very high DDT-resistant population of Anopheles pharoensis Theobald (Diptera: Culicidae) from Gorgora, northern Ethiopia. Parasite. 2006;13:327-9.

30. Balkew M, Ibrahim M, Koekemoer LL, Brooke BD, Engers H, Aseffa A, et al. Insecticide resistance in Anopheles arabiensis (Diptera: Culicidae) from villages in central, northern and south west Ethiopia and detection of kdr mutation. Parasit Vectors. 2010:3:40.

31. Fettene M, Koekemoer LL, Hunt RH, Coetzee M. PCR assay for identification of Anopheles quadriannulatus species B from Ethiopia and other sibling species of the Anopheles gambiae complex. Med Vet Entomol. 2002;16:214-7.

32. Ameneshewa B, Service MW. The relationship between female body size and survival rate of the malaria vector Anopheles arabiensis in Ethiopia. Med Vet Entomol. 1996:10:170-2.

33. Ameneshewa B, Service MW. Resting habits of Anopheles arabiensis in the Awash river valley of Ethiopia. Ann Trop Med Parasitol. 1996;90:515-21.

34. Massebo F, Balkew M, Gebre-Michael T, Lindtjorn B. Entomologic inoculation rates of Anopheles arabiensis in southwestern Ethiopia. Am J Trop Med Hyg. 2013;89:466-73.

35. Ghebreyesus TA, Haile M, Witten KH, Getachew A, Yohannes M, Lindsay SW, et al. Household risk factors for malaria among children in the Ethiopian highlands. Trans R Soc Trop Med Hyg. 2000;94:17-21.

36. Lindsay SW, Jawara M, Paine K, Pinder M, Walraven GE, Emerson PM Changes in house design reduce exposure to malaria mosquitoes. Trop Med Int Health. 2003:8:512-7.

\footnotetext{
Ready to submit your research? Choose BMC and benefit from:

- fast, convenient online submission

- thorough peer review by experienced researchers in your field

- rapid publication on acceptance

- support for research data, including large and complex data types

- gold Open Access which fosters wider collaboration and increased citations

- maximum visibility for your research: over $100 \mathrm{M}$ website views per year
}

At BMC, research is always in progress.

Learn more biomedcentral.com/submissions 